Article

\title{
Nitrogen Doped Ordered Mesoporous Carbon as Support of PtRu Nanoparticles for Methanol Electro-Oxidation
}

\author{
David Sebastián ${ }^{1, *(1)}$, María Jesús Nieto-Monge ${ }^{1}$, Sara Pérez-Rodríguez ${ }^{1}$, Elena Pastor ${ }^{2}$ and \\ María Jesús Lázaro ${ }^{1, * \text { (i) }}$ \\ 1 Instituto de Carboquímica (CSIC), Miguel Luesma Castán 4, 50018 Zaragoza, Spain; \\ mjnieto@icb.csic.es (M.J.N.-M.); sperez@icb.csic.es (S.P.-R.) \\ 2 Dpto. Química-Física, Universidad de La Laguna, Avda. Astrofísico Francisco Sánchez s/n, \\ 38071 La Laguna, Spain; epastor@ull.es \\ * $\quad$ Correspondence: dsebastian@icb.csic.es (D.S.); mlazaro@icb.csic.es (M.J.L.); Tel.: +34-976-733-977 (D.S.)
}

Received: 23 February 2018; Accepted: 30 March 2018; Published: 4 April 2018

Abstract: The low oxidation kinetics of alcohols and the need for expensive platinum group metals are still some of the main drawbacks for the commercialization of energy efficient direct alcohol fuel cells. In this work, we investigate the influence of nitrogen doping of ordered mesoporous carbon $(\mathrm{CMK})$ as support on the electrochemical activity of PtRu nanoparticles. Nitrogen doping procedures involve the utilization of pyrrole as both nitrogen and carbon precursor by means of a templating method using mesoporous silica. This method allows obtaining carbon supports with up to $14 \mathrm{wt}$ \% nitrogen, with an effective introduction of pyridinic, pyrrolic and quaternary nitrogen. $\mathrm{PtRu}$ nanoparticles were deposited by sodium formate reduction method. The presence of nitrogen mainly influences the Pt:Ru atomic ratio at the near surface, passing from 50:50 on the bare (un-doped) CMK to 70:30 for the N-doped CMK catalyst. The electroactivity towards the methanol oxidation reaction (MOR) was evaluated in acid and alkaline electrolytes. The presence of nitrogen in the support favors a faster oxidation of methanol due to the enrichment of $\mathrm{Pt}$ at the near surface together with an increase of the intrinsic activity of PtRu nanoparticles.

Keywords: N-doped; ordered mesoporous carbons; PtRu catalysts; methanol oxidation reaction; fuel cells

\section{Introduction}

Direct alcohol fuel cells represent a good alternative to current systems for the production of electricity, especially in low power consumers (laptop, cell phones, etc.) [1-4]. The use of methanol as fuel (instead of hydrogen, which is conventionally used in low temperature fuel cells) presents several advantages such as its high volume energy-density and easy storage/transportation, which allows using existing infrastructures [5]. However, challenging issues must be addressed in order to commercialize the direct methanol fuel cell (DMFC) technology [6], like the low catalytic activity for the methanol oxidation reaction (MOR) on anode electrode, catalyst poisoning by the formation of CO-like intermediates during MOR and high costs of the Pt-based electrocatalysts [5].

In recent years, great efforts have been made to design efficient and stable catalysts for MOR, especially in binary catalytic systems, such as PtRu [7-11], PtCu [12] or PtCo [13]. Among them, bimetallic electrocatalysts of PtRu are considered to date the most promising anode catalysts for methanol oxidation [5], where Pt sites dehydrogenate methanol and Ru oxidizes the CO intermediates into $\mathrm{CO}_{2}$ [2]. 
In order to enhance the dispersion and activity/stability of metal nanoparticles, nanostructured carbon materials are commonly used as electrocatalyst supports, such as carbon blacks [14], carbon nanofilaments [14-18], graphene [13,19], carbon gels [18,20,21] or mesoporous carbon [18,22-26]. Among them, ordered mesoporous carbons have attracted special attention in the field of electrocatalysis due to their developed mesoporosity and regular pore channels [22-24], which may facilitate a high nanoparticle dispersion and reactant/product diffusion to/from the active sites. In particular, a series of ordered mesoporous carbons synthesized by the nanocasting method from mesoporous silica and denoted as CMKs (denoted in the literature as CMKs, standing for carbon mesostructures from Korea) have been widely used as catalyst support obtaining promising results [22,27]. Interestingly, Maiyalagan and coworkers [22] reported a higher activity and stability on PtRu nanoparticles supported on CMK-8 in comparison to the commercial PtRu/C catalyst (E-TEK).

On the other hand, the physicochemical properties of carbon materials can be tuned by the introduction of different heteroatoms (such as N, B, S or P) into the carbon structure [28-35]. In general, doping carbon materials with nitrogen leads to a high dispersion of smaller nanoparticles with narrower size distributions, and consequently, higher catalytic activities toward MOR have been reported on $\mathrm{N}$-doped carbon/catalyst systems compared to undoped analogues $[15,16,19,29,36,37]$. In this context, Liu et al. [36] showed a high catalytic activity for methanol oxidation of PtRu nanoparticles supported on $\mathrm{N}$-doped porous carbon nanospheres, which was attributed to the presence of nitrogen functional groups and the high dispersion of the nanoparticles. On the other hand, Kang and coworkers [37] showed a much better catalytic performance when a nanotube-graphene hybrid nanostructure was doped with nitrogen compared to electrodes based on conventional carbon nanotubes or commercial catalysts.

In this work, we report an investigation of the influence of nitrogen doping in ordered mesoporous carbon materials as support for PtRu catalysts. Pyrrole was studied as both nitrogen and carbon source. We demonstrate that the effective introduction of pyrrolic, pyridinic and quaternary nitrogen groups in the carbon support leads to a positive effect on the electrocatalytic activity for the oxidation of methanol on PtRu nanoparticles.

\section{Results}

\subsection{Physico-Chemical Properties of N-Doped Carbon Materials}

Ordered mesoporous carbons were synthesized by impregnating a silica template (SBA-15) with two different carbon precursors: a nitrogen-free precursor, furanic resin (the resulting carbon will be labelled in this work as CMK), and pyrrole. Pyrrole, a nitrogen-rich organic molecule ( $20.9 \mathrm{wt} . \% \mathrm{~N})$, was infiltrated into the silica pores following two strategies: directly impregnating the liquid into the porosity of the silica powder (labelled CMK-N-imp), or flowing its vapor through the solid (labelled CMK-N-vap). For more details, please refer to the Experimental section. All materials were thermally treated for the carbonization of the carbon (or carbon/nitrogen) precursor and etched in HF to remove the silica template. Using pyrrole as precursor is advantageous since it serves both as carbon and nitrogen source simultaneously.

The amount of nitrogen in N-doped CMKs is about $14 \mathrm{wt}$. \% (Table 1) according to elemental analysis (EA). The amorphous nature of carbon in CMKs, with a high density of defects and high surface area, together with the templating process, favor the doping extent of the carbon matrix with nitrogen. X-ray photoelectron spectroscopy (XPS) was utilized to investigate the chemical composition at the near surface, resulting in a nitrogen content between 8 and 10 at \%. By comparing bulk (EA) and surface (XPS) analysis results, it appears that using pyrrole vapor as precursor favors the presence of nitrogen atoms on the surface, since the atomic percentage in XPS results is 2.2 at $\%$ higher for the CMK-N-vap sample while bulk analyses do not indicate significant differences $(<0.5 \mathrm{wt}$. \%). However, the XPS profile (Figure 1a,b) for N1s barely changes between CMK-N-imp and CMK-N-vap, pointing to a similar nitrogen speciation, as will be explained later. 
Table 1. Physico-chemical features of N-doped ordered mesoporous carbon materials.

\begin{tabular}{ccccccc}
\hline Material & $\begin{array}{c}\text { Nitrogen Content/wt. \% } \\
\text { (EA) }\end{array}$ & $\begin{array}{c}\text { Nitrogen Content/at \% } \\
\text { (XPS) }\end{array}$ & $\begin{array}{c}\mathbf{S}_{\mathbf{B E T}} / \mathbf{m}^{2} \\
\mathbf{g}^{-1}\end{array}$ & $\begin{array}{c}\mathbf{V}_{\text {pore }} / \mathbf{c m}^{3} \\
\mathbf{g}^{-1}\end{array}$ & $\begin{array}{c}\mathbf{V}_{\text {micropore }} / \mathbf{c m}^{3} \\
\mathbf{g}^{-1}\end{array}$ & $\begin{array}{c}\mathbf{V}_{\text {mesopore }} / \mathbf{c m}^{3} \\
\mathbf{g}^{-1}\end{array}$ \\
\hline CMK & $<0.1$ & 0.1 & 1006 & 0.68 & 0.47 & 0.21 \\
CMK-N-imp & 14.2 & 7.9 & 151 & 0.14 & 0.01 & 0.13 \\
CMK-N-vap & 13.7 & 10.1 & 886 & 0.88 & 0.24 & 0.64 \\
\hline
\end{tabular}

The most significant difference between the two nitrogen doping treatments is the detrimental effect of direct impregnation on the porous structure of CMK-N-imp. In this case, the surface area $\left(\mathrm{S}_{\mathrm{BET}}\right)$ is about 6-fold lower than in the CMK-N-vap, derived from pyrrole vapor impregnation. The latter presents a similar $\mathrm{S}_{\mathrm{BET}}$ than the $\mathrm{CMK}$ from the furanic resin, considering also the different nature of the precursor. However, a more developed mesoporosity and consequently a larger total pore volume was obtained for the CMK-N-vap material in comparison to CMK, which could be associated to a different pore covering of the silica template during the impregnation stage. The pore volume $\left(\mathrm{V}_{\text {pore }}\right)$ is also affected by the nitrogen incorporation procedure, indicating a much dense material resulting from the direct impregnation, presumably due to the formation of carbon agglomerates derived from pyrrole not entering efficiently into the porosity of the template.

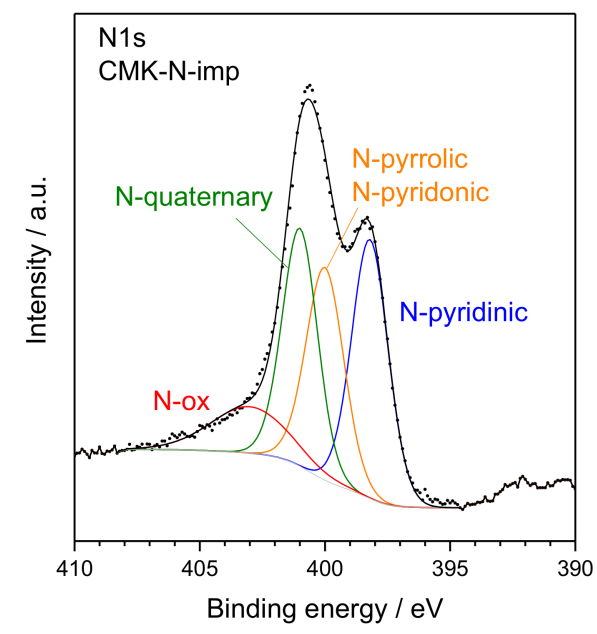

(a)

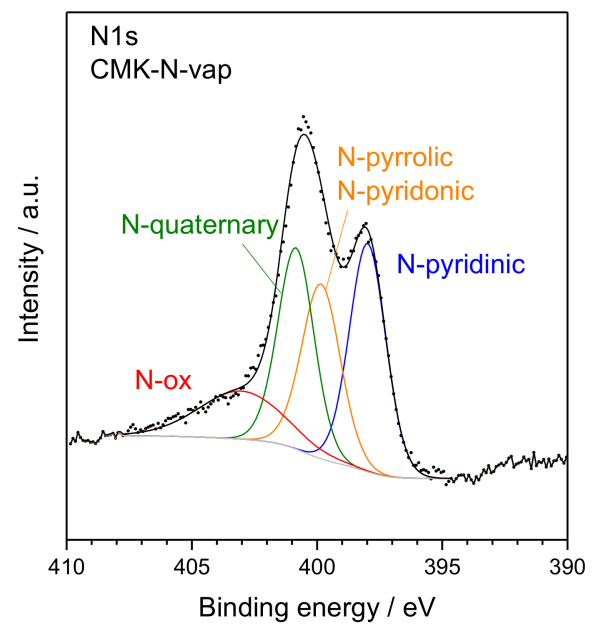

(b)

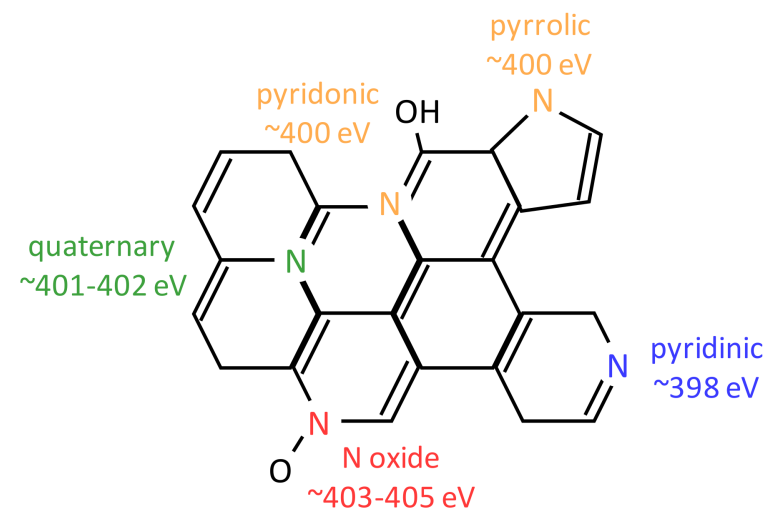

(c)

Figure 1. XPS high-resolution N1s spectra of: (a) CMK-N-imp; (b) CMK-N-vap; (c) Illustration of nitrogen groups in carbon and their associated binding energy $(\mathrm{eV})$.

The chemical speciation of nitrogen was evaluated by deconvoluting the high resolution N1s spectra into four contributions [28,38], as depicted in Figure 1 and summarized in Table 2. The types of 
nitrogen functionalities are represented in Figure 1c. The XPS spectra present two main peaks for both $\mathrm{N}$-doped CMKs, centered at about 398 and $400.5 \mathrm{eV}$, which are ascribed mainly to the presence of three main nitrogen-containing species: pyridinic, pyrrolic (or pyridonic) and quaternary nitrogen atoms.

Table 2. Nitrogen speciation from XPS analyses of N-doped carbon materials.

\begin{tabular}{|c|c|c|c|c|}
\hline Material & $\begin{array}{r}\text { Pyridinic N } \\
(398.2 \mathrm{eV}) / \%\end{array}$ & $\begin{array}{c}\text { Pyrrolic/Pyridonic N } \\
(400 \mathrm{eV}) / \%\end{array}$ & $\begin{array}{c}\text { Quaternary N } \\
(401 \mathrm{eV}) / \%\end{array}$ & $\begin{array}{c}\text { N Oxides } \\
(403-405 \mathrm{eV}) / \%\end{array}$ \\
\hline CMK-N-imp & 32.1 & 27.3 & 28.5 & 12.1 \\
\hline CMK-N-vap & 31.4 & 25.6 & 27.6 & 15.4 \\
\hline
\end{tabular}

From the analysis of N1s spectra, it appears that the method to introduce pyrrole by either liquid impregnation or vapor into the silica template does not significantly influence the chemical nature of nitrogen groups. Upon thermal treatment at $700{ }^{\circ} \mathrm{C}$, a significant percentage of pyrrolic nitrogen from the precursor converts to pyridinic and quaternary $\mathrm{N}$, in accordance to published results [39].

\subsection{Physico-Chemical Properties of N-Doped Carbon-Supported PtRu Catalysts}

$\mathrm{PtRu}$ nanoparticles were deposited on the carbon supports by reduction with formate ions, as described in more detail in the Experimental section. Due to the substantially lower surface area of CMK-N-imp, we decided to deposit a limited amount of metal ( $20 \mathrm{wt} . \%)$ in order to minimize the effect of porosity on metal particle size distribution. The chemical composition of the catalysts was elucidated by means of XPS and energy dispersive X-ray spectroscopy (EDX), whereas the crystallinity was studied by X-ray diffraction (XRD). Interestingly, the nitrogen atomic concentration (Table 3) is noticeably larger in the PtRu/CMK-N-vap catalyst compared to PtRu/CMK-N-imp, according to the content of the bare supports (Table 1).

Table 3. Physico-chemical features of PtRu/C catalysts.

\begin{tabular}{cccccccc}
\hline Catalyst & $\begin{array}{c}\text { N Content } \\
\text { (XPS) /at \% }\end{array}$ & $\begin{array}{c}\text { PtRu Crystallite } \\
\text { Size (XRD) } \mathbf{1} / \mathbf{n m}\end{array}$ & $\begin{array}{c}\text { Pt (111) } \\
\mathbf{2 \theta}\left(^{\circ}\right)\end{array}$ & $\begin{array}{c}\text { Lattice } \\
\text { Parameter (nm) }\end{array}$ & $\begin{array}{c}\text { X }_{\text {Ru in PtRu }} \\
\text { Alloy }\end{array}$ & $\begin{array}{c}\text { Pt:Ru Atomic } \\
\text { Ratio (EDX) }\end{array}$ & $\begin{array}{c}\text { Pt:Ru Atomic } \\
\text { Ratio (XPS) }\end{array}$ \\
\hline PtRu/CMK & - & 2.8 & 40.26 & 0.388 & 0.4 & $44: 56$ \\
PtRu/CMK-N-imp & 5.5 & 2.9 & 40.13 & 0.389 & 0.3 & $47: 53$ \\
PtRu/CMK-N-vap & 9.0 & 5.8 & 40.00 & 0.390 & 0.2 & $58: 42$ \\
\hline
\end{tabular}

${ }^{1}$ From Scherrer equation applied to $\mathrm{Pt}$ (220) reflection.

Figure 2 shows the X-ray diffractograms of the PtRu catalysts, while the structural parameters from XRD are displayed in Table 3. The reflections can be ascribed to the presence of crystalline Pt (JCPDS \#04-0802) together with a broad contribution of carbon (JCPDS \#01-0604) centered at about $2 \theta=25.9^{\circ}$, as indicated in the figure. The absence of Ru related reflections together with the shift of $\mathrm{Pt}$ reflections towards wider Bragg angles indicate that $\mathrm{Ru}$ is alloyed with Pt. This is confirmed by the contraction of the lattice parameter from $0.392 \mathrm{~nm}$ for Pt to $0.390-0.388 \mathrm{~nm}$ for the PtRu catalysts, indicating the formation of the PtRu alloy. The alloying degree was determined using Vegard's law [40]. Interestingly, the Ru content in the PtRu alloy decreases as the concentration of nitrogen increases (XPS, Table 3), from $\mathrm{X}_{\mathrm{Ru}}=0.4$ for the $\mathrm{N}$-free catalyst to values of 0.3 and 0.2 for PtRu/CMK-N-imp and PtRu/CMK-N-vap, respectively. A part of Ru might have been deposited on the carbon material as amorphous phase [41]. According to the bibliography [42,43], the un-alloyed amorphous Ru is generally found as oxide (i.e., $\mathrm{RuO}_{x}$ ). Additionally, the $\mathrm{Pt}: \mathrm{Ru}$ atomic ratio was determined by EDX and XPS. The Pt content in the bulk (EDX), about $45-58$ at \%, slightly increases with nitrogen content. This trend is exacerbated when examining the Pt:Ru ratio in the near surface (XPS), with about 70 at $\%$ of Pt for the PtRu/CMK-N-vap catalyst, characterized by the largest nitrogen content. Thus, the tintroduction of nitrogen on carbon structure seems to decrease the $\mathrm{Ru}$ alloyed with $\mathrm{Pt}$, as well as to enrich the Pt amount on the catalyst surface. This behavior could be related with a modification of the 
electronic structure of the carbon support by the introduction of nitrogen [29,44,45]. Kim et al. obtained a different surface metal composition in bimetallic catalysts $(\mathrm{PdPt})$ supported on nitrogen-doped materials in comparison with its nitrogen-free analogue [44]. The contribution of surface nitrogen on the reduction of $\mathrm{Pt}$ and $\mathrm{Ru}$ during the synthesis cannot be discarded. The yield of Ru reduction by formate ions relies on $\mathrm{pH}$, as demonstrated in previous works $[46,47]$. This indicates that different local $\mathrm{pH}$ might cause a variation in $\mathrm{Pt}$ and $\mathrm{Ru}$ reduction/deposition kinetics, thus contributing to the Pt surface enrichment.

The crystallite size of PtRu nanoparticles was calculated applying the Scherrer equation to the (220) peak at $2 \theta=68.1^{\circ}$. The crystallite sizes of PtRu/CMK and PtRu/CMK-N-imp were very similar (about $2.9 \mathrm{~nm}$ ) while the narrower XRD reflections of PtRu/CMK-N-vap indicate larger crystallite size, of $5.8 \mathrm{~nm}$. This may indicate some partial agglomeration of metallic crystallites during the reduction process in the presence of a larger nitrogen content. Nieto-Marquez et al. found a correlation between quaternary $\mathrm{N}$ concentration and the relative growth of $\mathrm{Ni}$ crystallites, attributed to enhanced electron mobility [48]. On mesoporous carbons, Pt nanoparticles are known to attach preferably on the surface of open mesopore walls. Whereas, most Pt particles are buried in micropores when microporous carbon materials are used as support [25]. In this work, the three carbon materials exhibited different textural properties (Table 1). However, a clear trend of the porosity and PtRu crystallite size has not been found, probably due to the relatively low metal concentration employed ( $20 \mathrm{wt}$. \%). As it will be shown in the discussion of TEM images, some particle agglomerates are formed during the synthesis process, giving place to a certain population of large noble metal particles that contribute to the narrowing of XRD reflections.

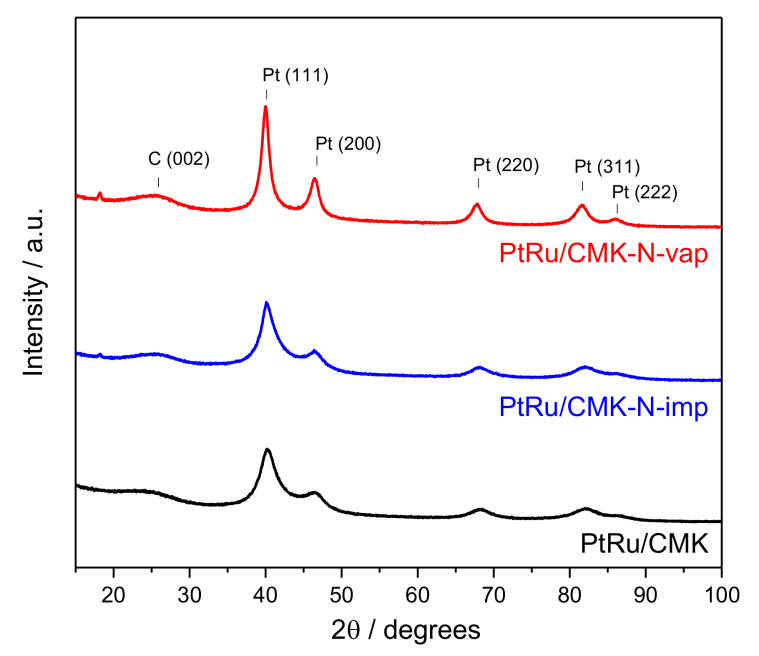

Figure 2. X-ray diffractograms of PtRu catalysts.

Transmission electron microscopy (TEM) images (Figure S1 of the Supplementary Information) of the catalysts at low magnification evidenced the ordered structure of the carbons supports. CMKs exhibit an arrangement of carbon nanorods with a uniform spacing (mesopores) between them. The morphology and distribution of PtRu nanoparticles on the surface of CMKs was also studied by TEM. Representative micrographs for all three PtRu/CMK catalysts are depicted in Figure 3a,c,e. $\mathrm{PtRu}$ particle size distributions are shown in Figure $3 b, d, f$ for these catalysts. PtRu nanoparticles appear well distributed on the carbonaceous surface, presenting some aggregation in a few localized zones, presumably due to the presence of surface defects or small pores that favor the growth of nanoparticles and a certain agglomeration on the support. 


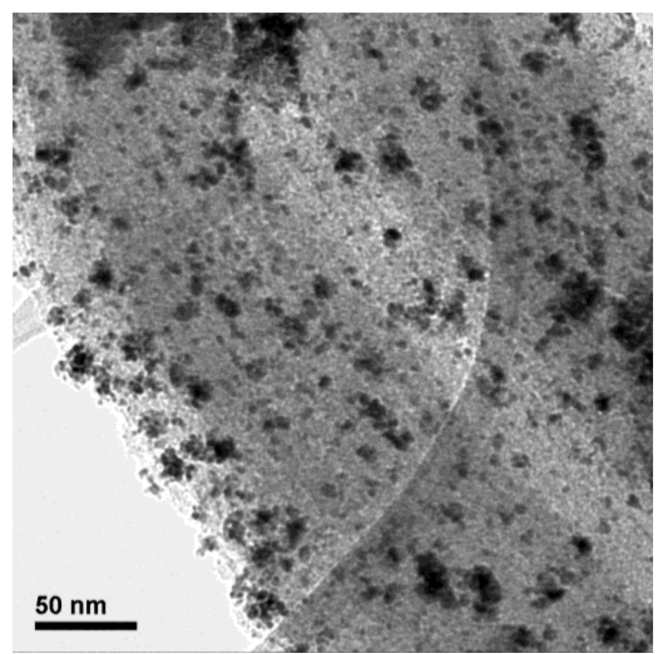

(a)

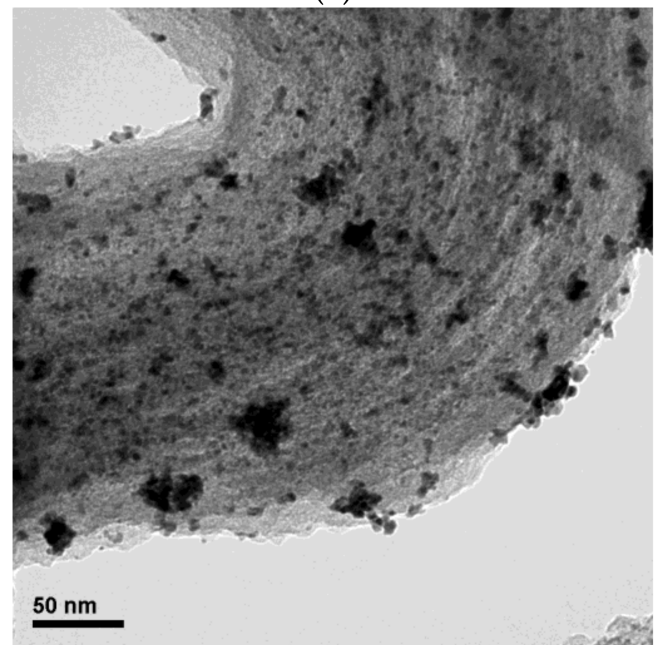

(c)

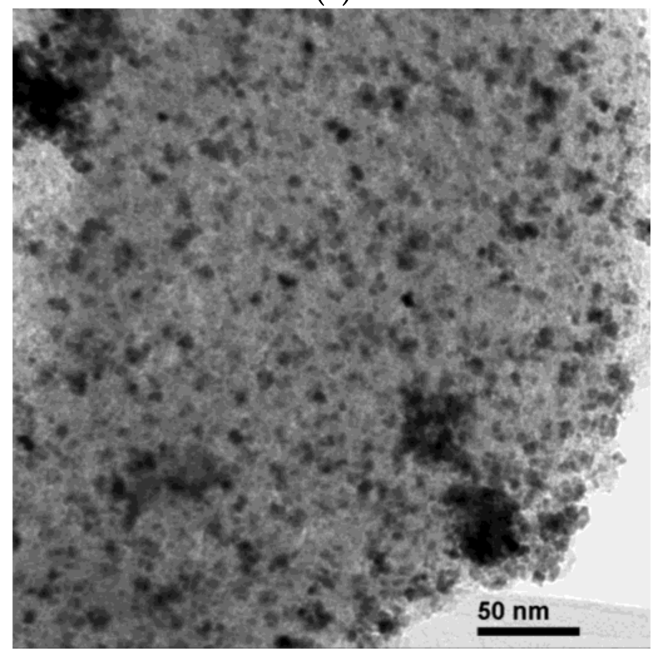

(e)

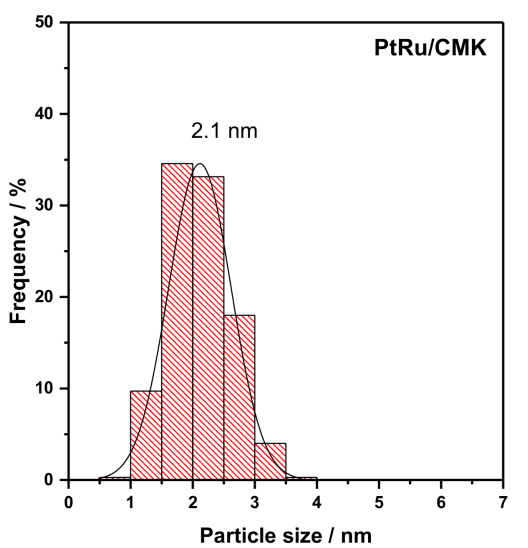

(b)

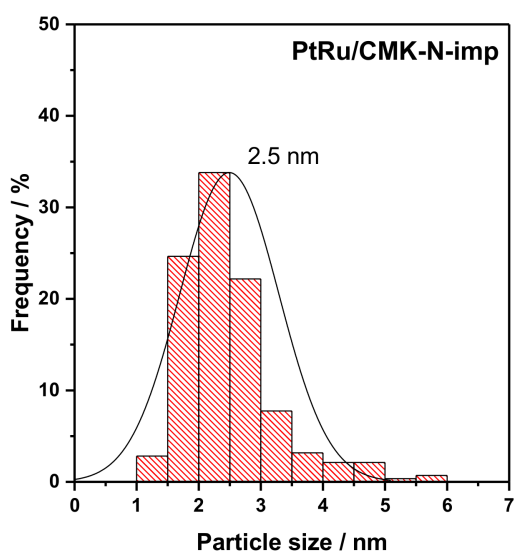

(d)

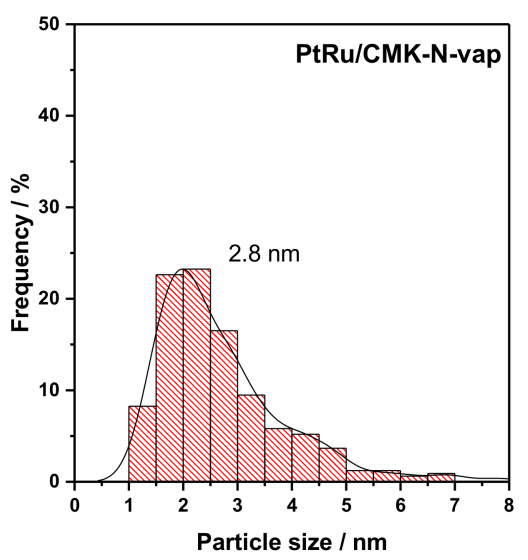

(f)

Figure 3. TEM images of (a) PtRu/CMK; (c) PtRu/CMK-N-imp and (e) PtRu/CMK-N-vap catalysts. PtRu particle size histograms of (b) PtRu/CMK; (d) PtRu/CMK-N-imp and (f) PtRu/CMK-N-vap catalysts. 
Particle size distributions (PtRu) are shown in Figure 3, obtained from the analysis of more than 300 particles by TEM. The average particle size slightly increases from $2.1 \mathrm{~nm}$ for the catalyst supported on the bare CMK to $2.8 \mathrm{~nm}$ for the PtRu/CMK-N-vap catalyst. Catalysts supported on N-doped CMKs present a distribution tail for particles larger than $3 \mathrm{~nm}$, more evident in the case of PtRu/CMK-N-vap catalyst, characterized by the largest amount of surface nitrogen according to XPS analyses (Table 3). These bigger nanoparticles contribute in a larger extent to $X$-ray diffraction, explaining the narrower reflections for the CMK-N-vap supported catalyst in XRD (Figure 2) and consequently larger crystallite size. Nonetheless, more than $50 \%$ population of particles are between 1.5 and $3.0 \mathrm{~nm}$ size regardless the nature of the support. Small nanoparticles represent the most important contribution to active surface area in surface sensitive reactions like methanol electrooxidation.

Aimed to investigate eventual effects of the chemical composition of the catalysts, XPS analyses were also carried out for the CMK-supported PtRu catalysts. The high resolution N1s spectra are depicted in Figure 4, whereas the Pt4f and Ru3p spectra are shown in Figure 5. The peak profile for nitrogen is very similar to the profiles obtained for the support alone, with about $33-34 \%$ as pyridinic $\mathrm{N}, 31-32 \%$ as pyrrolic/pyridonic nitrogen and $25-26 \%$ quaternary $\mathrm{N}$, as summarized in Table 4. The similar N1s XPS signal indicates a negligible effect of PtRu deposition on the chemical speciation of nitrogen in the carbonaceous phase.

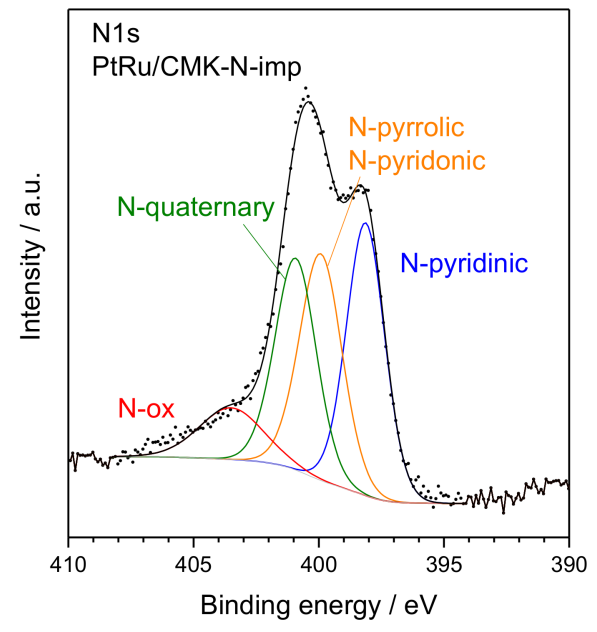

(a)

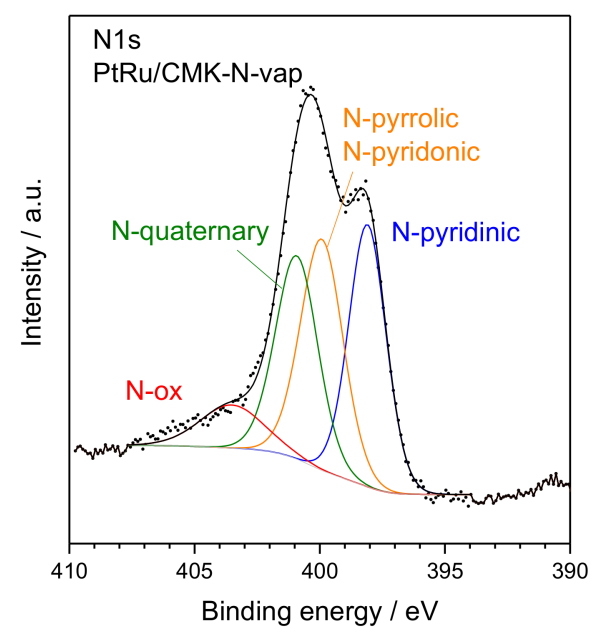

(b)

Figure 4. XPS high-resolution N1s spectra of: (a) PtRu/CMK-N-imp; (b) PtRu/CMK-N-vap.

Table 4. Physico-chemical features of N-doped carbon-supported PtRu catalysts from XPS analyses.

\begin{tabular}{ccccccc}
\hline Species & \multicolumn{2}{c}{ PtRu/CMK } & \multicolumn{2}{c}{ PtRu/CMK-N-imp } & \multicolumn{2}{c}{ PtRu/CMK-N-vap } \\
\hline & $\mathrm{BE} / \mathrm{eV}$ & $\%$ & $\mathrm{BE} / \mathrm{eV}$ & $\%$ & $\mathrm{BE} / \mathrm{eV}$ & $\%$ \\
\hline $\mathrm{Ru} 3 p$ 3/2 & & & & & & \\
Metallic $\mathrm{Ru}$ & 461.3 & 33.1 & 461.4 & 38.8 & 461.0 & 25.5 \\
$\mathrm{Ru}^{4+}$ & 463.0 & 35.0 & 463.0 & 33.9 & 463.0 & 42.0 \\
$\mathrm{Ru}^{4+}$ hydrate & 465.1 & 31.9 & 465.1 & 27.3 & 465.2 & 32.5 \\
\hline Pt $4 f$ 7/2 & & & & & & \\
Metallic Pt & 71.5 & 62.7 & 71.3 & 61.9 & 71.3 & 60.2 \\
Pt $^{2+}$ & 72.8 & 22.6 & 72.7 & 22.4 & 72.6 & 23.8 \\
Pt $^{4+}$ & 75.4 & 14.7 & 75.3 & 15.7 & 75.0 & 16.0 \\
\hline N 1s & & & & & & \\
Pyridinic N & - & - & 398.2 & 34.2 & 398.1 & 33.2 \\
Pyrrolic/Pyridonic N & - & - & 400.0 & 30.9 & 400.0 & 32.5 \\
Quaternary N & - & - & 401.0 & 24.9 & 401.0 & 25.9 \\
N oxides & - & - & 403.5 & 10.0 & 403.6 & 8.4 \\
\hline
\end{tabular}




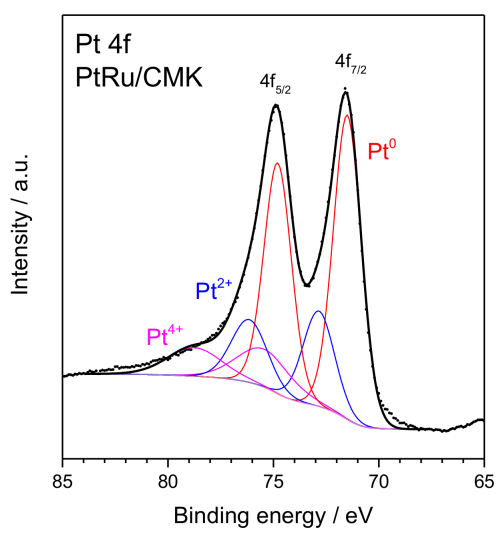

(a)

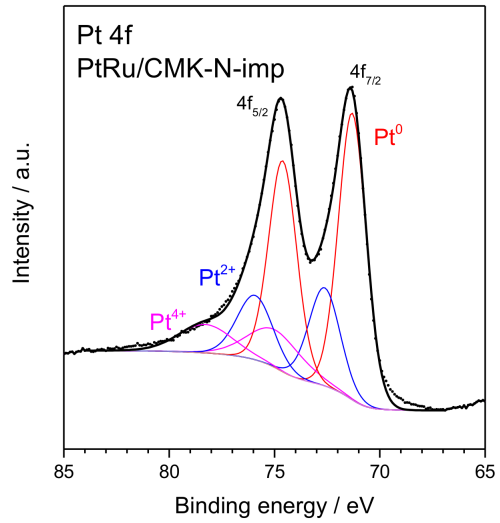

(c)

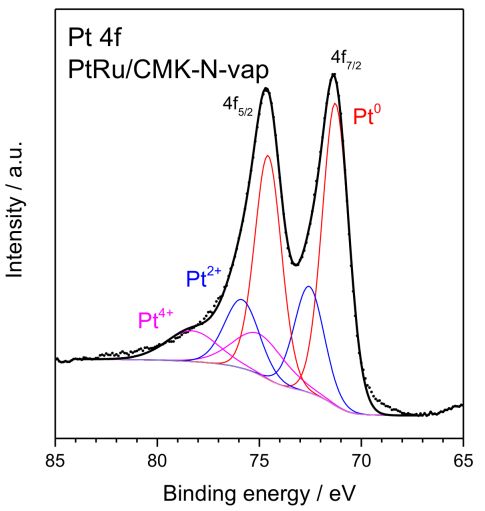

(e)

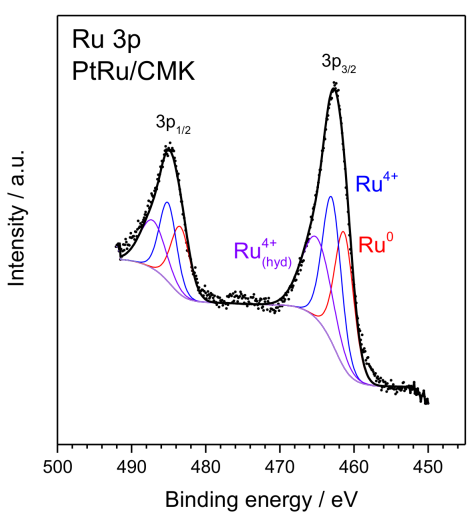

(b)

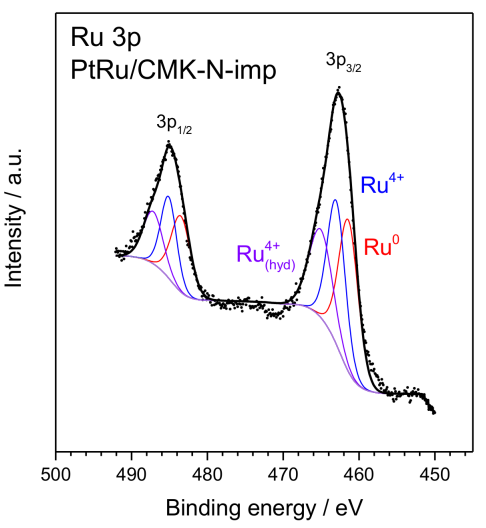

(d)

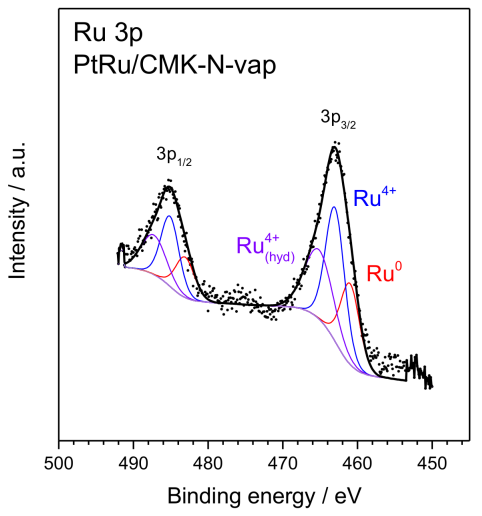

(f)

Figure 5. XPS high-resolution spectra of $\mathrm{Pt} 4 \mathrm{f}$ (left) and Ru 3p (right) for: $(\mathbf{a}, \mathbf{b}) \mathrm{PtRu} / \mathrm{CMK}$; (c,d) PtRu/CMK-N-imp; (e,f) PtRu/CMK-N-vap.

The deconvolution of Pt $4 \mathrm{f}$ spectra (Figure 5 and Table 4 ) indicate above 60 at \% of metallic Pt in all catalysts. The synthesis with sodium formate is effective in reducing a substantial percentage of $\mathrm{Pt}$, with no significant influence of the presence of nitrogen on its chemical state. Whereas, the binding energy (BE) associated to $\mathrm{Pt}^{0}$ is slightly shifted towards lower values, $0.2 \mathrm{eV}$, in the catalysts based on $\mathrm{N}$-doped CMKs. This small shift has been ascribed by some authors to the effect of surface nitrogen on the electronic environment of metal particles [15], which in the end may positively influence the electro-catalytic activity by favoring the electron transfer processes during the oxidation of methanol. It has been demonstrated that the lone pair of electrons at surface nitrogen sites in the $\mathrm{sp}^{2}$ orbital may favor a stronger binding of $\mathrm{Pt}$ and $\mathrm{Ru}$ during catalyst synthesis, leading to enhanced activity in MOR [49]. 
The oxidation state of $\mathrm{Ru}$, as analyzed from the deconvolution of Ru 3p spectra, varies slightly with the support characteristics. The broadening of each peak in the Ru $3 p$ doublet indicates the presence of both metallic $\mathrm{Ru}$ and oxidized $\mathrm{Ru}^{4+}$. The contribution of oxidized $\mathrm{Ru}$ to total is the highest for the PtRu/CMK-N-vap catalyst, which is characterized by the highest Pt:Ru atomic ratio at the surface (Table 3).

In summary, the presence of nitrogen species influences mainly the Pt:Ru ratio at the surface, according to XPS and EDX analyses, and the oxidation state of $\mathrm{Ru}$, although in a much lesser extent. Other important features remain unaltered, allowing us a proper discussion of the influence of nitrogen doping in the electro-catalytic activity of carbon-supported PtRu catalysts.

\subsection{Electrochemical Assessment of Activity for Methanol Electro-Oxidation on CMK-Supported PtRu Catalysts}

$\mathrm{PtRu} / \mathrm{C}$ catalysts were evaluated in the methanol oxidation reaction (MOR) both in acid $\left(0.5 \mathrm{M} \mathrm{H}_{2} \mathrm{SO}_{4}\right)$ and alkaline $(0.1 \mathrm{M} \mathrm{NaOH})$ environments. Figure 6 shows linear sweep voltammetric profiles for the MOR. In both acid and alkaline electrolytes, the PtRu catalysts supported on N-modified CMKs show better performances than the one supported on bare CMK.

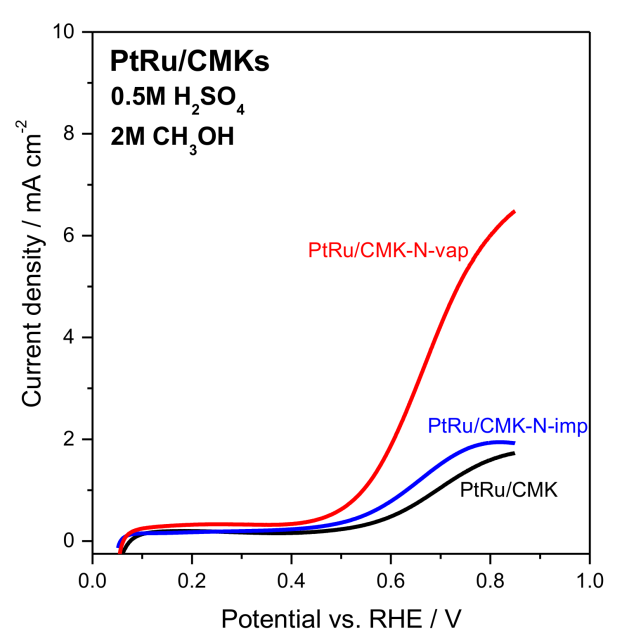

(a)

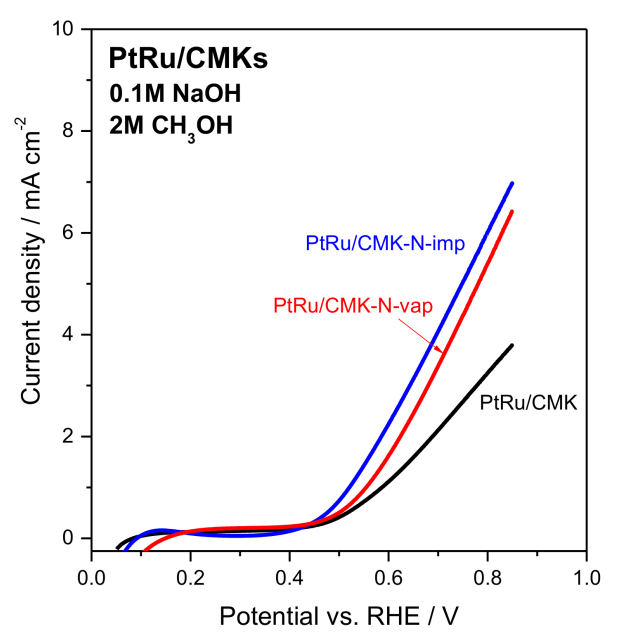

(b)

Figure 6. Electrooxidation of methanol by linear sweep voltammetry at $20 \mathrm{mV} \mathrm{s}^{-1}$ in deareated $2 \mathrm{M}$ methanol $\left(\mathrm{CH}_{3} \mathrm{OH}\right)$ in: (a) $0.5 \mathrm{M} \mathrm{H}_{2} \mathrm{SO}_{4}$ electrolyte; (b) $0.1 \mathrm{M} \mathrm{NaOH}$ electrolyte. Room temperature, $50 \mu \mathrm{g} \mathrm{PtRu} \mathrm{cm}{ }^{-2}$.

In acid electrolyte (Figure 6a), the onset potential in the oxidation of methanol appears at significantly more negative values (lower overpotential) for the PtRu/CMK-N-vap catalyst compared to the other two formulations. The current density increase follows the same trend than surface nitrogen concentration (XPS) in the support. This enhancement could be explained by the partial enrichment of $\mathrm{Pt}$ at the surface or it could be a result of a better metal-support interaction. At low temperature (here room temperature) and acid environment, the dehydrogenation of methanol is a slow step conditioning the rate of the whole oxidation process. In the bifunctional MOR mechanism, the key role of $\mathrm{Pt}$ is dehydrogenating the organic molecule to give adsorbed $\mathrm{CO}$, which is further oxidized to $\mathrm{CO}_{2}$ by the formation of hydroxyl species on the surface of Ru atoms [40]. In our work, $\mathrm{PtRu}$ catalysts supported on N-doped CMKs present similar or even larger particle size than the one supported on the bare CMK, which means similar or even lower metal surface area. The current density is a function of the product between the available surface area $\left(\mathrm{m}^{2} \mathrm{~g}^{-1}\right)$ and the intrinsic activity $\left(\mathrm{A} \mathrm{m}^{-2}\right)$ for equivalent catalyst loadings on the working electrode. This means that the higher activity of catalysts supported on N-doped CMKs, with similar or lower surface area, is a result of a larger intrinsic activity compensating the lower surface from bigger nanoparticles. A larger 
intrinsic activity can be ascribed to enhanced surface methanol oxidation kinetics. As a consequence, catalysts with a larger surface Pt:Ru ratio, together with a favoring interaction of metal particles with the nitrogen-doped support, present improved behavior for the MOR, like PtRu/CMK-N-vap.

In alkaline electrolyte (Figure $6 \mathrm{~b}$ ) the situation is different. Even though $\mathrm{N}$-doped catalysts present higher current densities than the bare CMK one, the trend of activity is not related to the amount of nitrogen, like in the case of acid electrolyte. Similar current-voltage behavior was observed for $\mathrm{PtRu} / \mathrm{CMK}-\mathrm{N}$-vap and PtRu/CMK-N-imp, with about $40 \mathrm{mV}$ difference between them, the latter being more active. Interestingly, the highest activity was observed for the catalyst supported on CMK-N-imp in alkaline environment. Methanol oxidation kinetics are affected by both $\mathrm{pH}$ and adsorbing anions, these latter having an inhibiting effect on methanol dehydrogenation steps [50]. Apparently, the interactions between PtRu nanoparticles and the N-doped CMKs are somehow influenced by the electrolyte. In sulfuric acid, it appears that either the coverage of $\mathrm{OH}^{-}$species from oxidative water decomposition in acid, or the adsorption of sulfate anions, affect in a larger and more negative extent to the PtRu/CMK-N-imp catalyst, characterized by the least developed porosity among the samples herein investigated. Whereas, in alkaline electrolyte, where $\mathrm{OH}^{-}$discharge is favored, the characteristics of N-doped CMK-supported PtRu catalysts aid in methanol oxidation, presumably due to favored metal-support interaction from enhanced Lewis basicity derived from strong $\pi$ electron delocalization of $\mathrm{N}$-doped carbon increasing the electron-donor capacity of the support [51].

Chronoamperometric curves were carried out to assess the behavior of the PtRu catalysts under constant potential conditions. Figure 7 shows the current density-time curves obtained at $0.5 \mathrm{~V}$ vs. RHE. The curves exhibit the typical current drop in the very first seconds associated to the oxidation of methanol adsorbed on the catalyst thin layer when applying $0.5 \mathrm{~V}$ vs. RHE, followed by a slower variation with time, ascribed to the oxidation of methanol under steady-state conditions. In sulfuric acid (Figure 7a), PtRu/CMK-N-vap presents the highest current density with about twice the current obtained with the other two catalysts. In alkaline electrolyte (Figure $7 \mathrm{~b}$ ) the current densities are higher than in acid electrolyte for the same catalyst. It is well known that the methanol oxidation kinetics in alkaline environment is faster than in acid [50]. Under constant potential, the differences among the three tested catalysts are exacerbated in $0.1 \mathrm{M} \mathrm{NaOH}$. Considering the similarities found in the catalysts with regard to some key features controlling the oxidation of methanol, like particle size, metal oxidation state and composition, a significant part of the electro-catalytic enhancement must derive from the influence of nitrogen on the metal-support interaction.

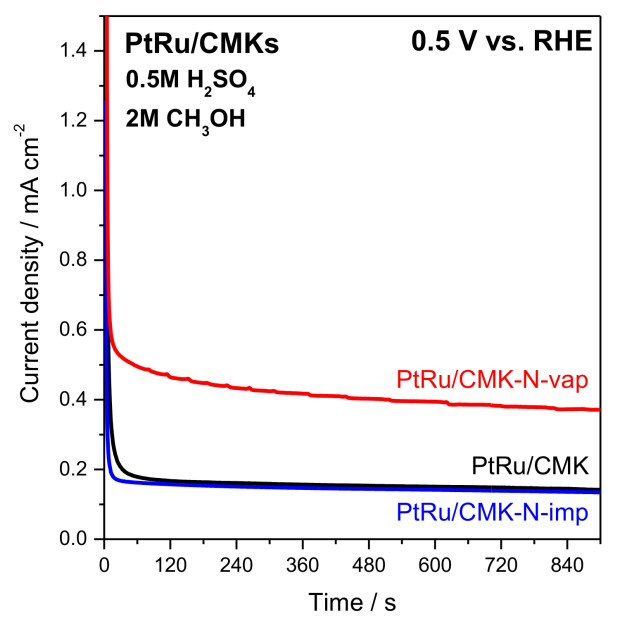

(a)

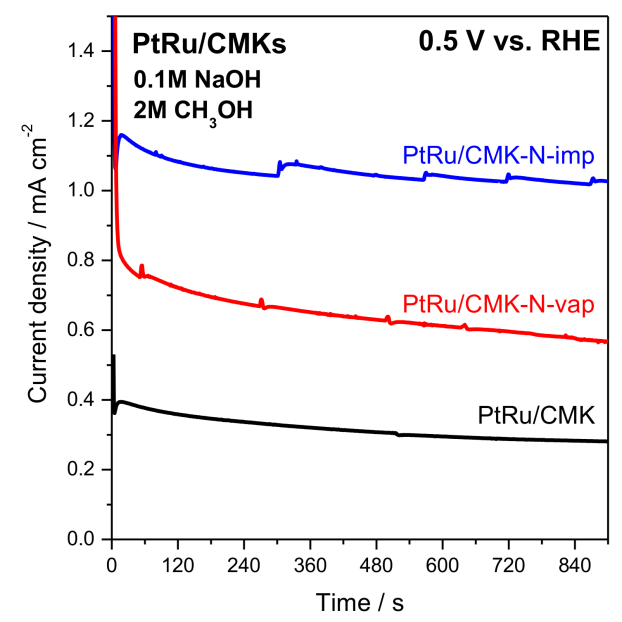

(b)

Figure 7. Electrooxidation of methanol by chronoamperometry at $0.5 \mathrm{~V}$ vs. RHE for $900 \mathrm{~s}$ in deareated $2 \mathrm{M}$ methanol $\left(\mathrm{CH}_{3} \mathrm{OH}\right)$ in: (a) $0.5 \mathrm{M} \mathrm{H}_{2} \mathrm{SO}_{4}$ electrolyte; (b) $0.1 \mathrm{M} \mathrm{NaOH}$ electrolyte. Room temperature, $50 \mu \mathrm{g} \mathrm{PtRu} \mathrm{cm}{ }^{-2}$. 
Table 5 summarizes the values of current density for all the catalysts, both in acid and alkaline electrolytes and according to linear voltammetry (LV, $0.55 \mathrm{~V}$ vs. RHE) and chronoamperometry (CA, $0.5 \mathrm{~V}$ vs. RHE) experiments. The current normalization was carried out considering the $\mathrm{Pt}$ loading in the electrode to better compare results regardless the amount of deposited catalyst. Similar conclusions can be extracted than those discussed above, with PtRu/CMK-N-vap as the best MOR catalyst in acid and PtRu/CMK-N-imp being the most performing in alkaline electrolyte.

Table 5. Electrochemical mass activity towards methanol oxidation of PtRu catalysts.

\begin{tabular}{|c|c|c|c|c|}
\hline Catalyst & $\begin{array}{c}\mathrm{LV}^{1} \text { MOR Activity at } \\
0.55 \mathrm{~V} \mathrm{vs.} \mathrm{RHE} \mathrm{in} 0.5 \mathrm{M} \\
\mathrm{H}_{2} \mathrm{SO}_{4} / \mathrm{mA} \mathrm{mg}_{\mathrm{Pt}}{ }^{-1}\end{array}$ & $\begin{array}{l}\mathrm{LV}^{1} \text { MOR Activity at } \\
0.55 \mathrm{~V} \text { vs. RHE in } 0.1 \mathrm{M} \\
\mathrm{NaOH} / \mathrm{mA} \mathrm{mg}_{\mathrm{Pt}^{-1}}^{-1}\end{array}$ & $\begin{array}{c}\mathrm{CA}^{2}(\mathrm{t}=10 \mathrm{~min}) \\
\text { MOR Activity at } 0.5 \mathrm{~V} \\
\text { vs. RHE in } 0.5 \mathrm{M} \\
\mathrm{H}_{2} \mathrm{SO}_{4} / \mathrm{mA} \mathrm{mg}_{\mathrm{Pt}}{ }^{-1}\end{array}$ & $\begin{array}{c}\mathrm{CA}^{2}(\mathrm{t}=10 \mathrm{~min}) \\
\text { MOR Activity at } 0.5 \mathrm{~V} \\
\text { vs. RHE in } 0.1 \mathrm{M} \\
\mathrm{NaOH} / \mathrm{mA} \mathrm{mg} \mathrm{Pt}^{-1}\end{array}$ \\
\hline $\mathrm{PtRu} / \mathrm{CMK}$ & 11.6 & 24.2 & 4.6 & 10.0 \\
\hline PtRu/CMK-N-imp & 16.2 & 45.3 & 4.4 & 32.9 \\
\hline PtRu/CMK-N-vap & 30.0 & 25.6 & 11.0 & 16.8 \\
\hline
\end{tabular}

${ }^{1}$ Linear sweep voltammetry; ${ }^{2}$ Chronoamperometry.

\section{Materials and Methods}

\subsection{Preparation of Ordered Mesoporous Carbons}

CMKs were synthesized by the carbonization of a carbon precursor impregnated in a mesoporous silica, SBA-15, as described in previous works [52,53]. In the case of bare CMKs, the carbon precursor was a furanic resin (furfuryl alcohol and formaldehyde, Huttenes-Albertus, Düsseldorf, Germany). Whereas, for N-doped CMKs, pyrrole (Sigma Aldrich, Saint Louis, MO, USA) was used as precursor. In a first strategy, $50 \mathrm{~mL}$ of pyrrole was directly impregnated into $1 \mathrm{~g}$ of silica (SBA-15) by stirring the mixture during $20 \mathrm{~h}$ (CMK-N-imp). A second strategy consisted of flowing pyrrole vapor $\left(40^{\circ} \mathrm{C}\right)$ through the SBA-15 during $24 \mathrm{~h}$ (CMK-N-vap), as described in [54]. Afterwards, the method was the same for both $\mathrm{N}$-doped CMK materials: the solid was mixed in a $0.5 \mathrm{M} \mathrm{FeCl}_{3}$ aqueous solution for $2 \mathrm{~h}$. It was subsequently washed with water and acetone and dried overnight in an oven. To obtain the carbonaceous material, the three mixtures (two from pyrrole and one from furanic resin) were thermally treated at $700{ }^{\circ} \mathrm{C}$ in inert atmosphere during $3 \mathrm{~h}$. Finally, to remove the silica template, each carbonaceous material was etched with HF during $24 \mathrm{~h}$, thoroughly washed with water and dried overnight at $70{ }^{\circ} \mathrm{C}$.

\subsection{Synthesis of Carbon-Supported PtRu Electrocatalysts}

PtRu electrocatalysts were synthesized by a sodium formate reduction method, as described in previous works [46]. Briefly, the metal precursors $\left(\mathrm{H}_{2} \mathrm{PtCl}_{6}\right.$ and $\mathrm{RuCl}_{3}$, Sigma-Aldrich, St. Louis, $\mathrm{MO}$, USA) were dissolved in formic acid ( $98 \%$, Merck, Kenilworth, NJ, USA) under sonication and the $\mathrm{pH}$ was adjusted to 12 by adding $1 \mathrm{M} \mathrm{NaOH}$ aqueous solution. After that, CMKs were dispersed in the solution containing the metal precursors and the mixture was refluxed at $80^{\circ} \mathrm{C}$ for $2 \mathrm{~h}$. The resultant catalysts were filtered, washed with ultrapure water and dried at $70{ }^{\circ} \mathrm{C}$ overnight.

\subsection{Physicochemical Characterization}

$\mathrm{N}_{2}$ adsorption-desorption isotherms of CMKs were measured at $-196{ }^{\circ} \mathrm{C}$ with a Micromeritics ASAP 2020. The total surface area was determined from BET (Brunauer, Emmett and Teller) equation and the total pore volume was estimated using the single point method at $P / P_{0}=0.99$. The micropore volume was obtained by the $t$-plot method, while the mesopore volume was estimated as the difference between the total pore volume and the micropore one.

EA of carbon supports were carried out with a CHNS Analyzer Thermo FlashEA 1112 (Thermo Fisher Scientific, Waltham, MA, USA). 
TEM micrographs of PtRu catalysts were obtained using a JEOL-2000 FXII microscope with a $\mathrm{LaB}_{6}$ filament. The samples were grounded, dispersed in ethanol and then a drop of solution was deposited on a copper grid covered with Lacey carbon film. The analysis of particle size distribution was carried out using ImageJ (version 1.50i) and OriginLab software (OriginPro 2015).

X-ray diffraction (XRD) patterns of the materials were recorded using a Bruker AXS D8 Advance (Bruker AXS, Karlsruhe, Germany) diffractometer with a $\theta-\theta$ configuration and using $\mathrm{Cu} K \alpha$ radiation $(\lambda=0.15406 \mathrm{~nm})$ at a scan rate of $1^{\circ} \mathrm{min}^{-1}$ for $2 \theta$ values from $10^{\circ}$ to $100^{\circ}$. Crystallite sizes were calculated from Debye-Scherrer equation and considering the (220) reflection peak of Pt.

A scanning electron microscopy—energy Dispersive X-ray (SEM-EDX) analyzer Röntec XFlash $\mathrm{Si}(\mathrm{Li})$ was used to determine the $\mathrm{Pt}$ and $\mathrm{Ru}$ bulk elemental composition.

XPS measurements were performed using a ESCAPlus OMICRON system equipped with a hemispherical electron energy analyser. A non-monochromatic $\mathrm{Al} \mathrm{K} \alpha(1486.7 \mathrm{eV})$ anode was used operating at $225 \mathrm{~W}(15 \mathrm{~mA}, 15 \mathrm{kV})$ and under vacuum $\left(<5 \times 10^{-9}\right.$ Torr $)$. A survey scan $(1$ sweep $/ 200 \mathrm{~ms}$ dwell) was acquired between 0 and $1100 \mathrm{eV}$, at $0.5 \mathrm{eV}$ step, $0.2 \mathrm{~s}$ dwell and $50 \mathrm{eV}$ pass energy. Detailed scans for N 1s, Pt $4 \mathrm{f}$ and Ru $3 p$ were obtained at $0.1 \mathrm{eV}$ step, $0.5 \mathrm{~s}$ dwell and $20 \mathrm{eV}$ pass energy. C 1s binding energy (BE) of the graphitic peak was referenced at $284.6 \mathrm{eV}$ for calibration. The quantitative evaluation of each peak was obtained by dividing the integrated peak area by atomic sensitivity factors and using the CasaXPS software after Shirley background subtraction and $70 \% / 30 \%$ Gauss/Lorentzian peaks. XPS data were interpreted by using the NIST X-ray Photoelectron Spectroscopy Database (NIST Standard Reference Database 20, Version 4.1) [55] and the Physical Electronics Handbook of X-ray photoelectron spectroscopy [56].

\subsection{Electrochemical Characterization}

Electrochemical performance of PtRu electrocatalysts was evaluated in a three-electrode electrochemical cell at room temperature using an Autolab PGSTAT302 potentiostat/galvanostat (Metrohm). The counter electrode was a high surface area carbon rod and a reversible hydrogen electrode (RHE) placed inside a Luggin capillary was used as reference. All potentials in the text are referred to the latter electrode. The working electrodes were prepared by depositing a thin electrocatalyst layer on a pyrolitic graphite disk $(7 \mathrm{~mm}$ diameter). The electrocatalyst layer was obtained by sonicating an ink containing $1 \mathrm{mg} \mathrm{mL}^{-1}$ of the catalyst in isopropyl alcohol and Nafion (30 wt. \% ionomer, $70 \mathrm{wt}$. \% catalyst). Subsequently, an aliquot of the ink was deposited onto the carbon disk for a PtRu loading of $50 \mu \mathrm{g} \mathrm{cm}^{-2}$, and dried at room temperature.

Sulphuric acid (96\%, Panreac) and sodium hydroxide (99.99\%, Sigma-Aldrich) were used for the preparation of the base electrolytes: $0.5 \mathrm{M} \mathrm{H}_{2} \mathrm{SO}_{4}$ and $0.1 \mathrm{M} \mathrm{NaOH}$, respectively. First, potential cycles were performed from 0.05 and $0.85 \mathrm{~V}$ vs. RHE at $100 \mathrm{mV} \mathrm{s}^{-1}$, to clean and activate the electrode surface. Methanol electrooxidation was evaluated by linear sweep voltammetry and chronoamperometry in a methanol solution in the base electrolyte. Linear sweep voltammetries were carried out from 0.05 to $0.85 \mathrm{~V}$ vs. RHE at a scan rate of $20 \mathrm{mV} \mathrm{s}^{-1}$. Current transients were recorded at $0.5 \mathrm{~V}$ vs. RHE during $900 \mathrm{~s}$. Methanol concentration in the solution was $2 \mathrm{M}$ for all the experiments. All currents were normalized considering the geometrical area of the electrode $\left(0.38 \mathrm{~cm}^{2}\right)$.

\section{Conclusions}

Ordered mesoporous carbon materials have been doped with nitrogen by using pyrrole as nitrogen and carbon precursor in a mesoporous silica template. The chemical and porous features have been investigated, concluding that an adequate porosity is favored when impregnating the silica template with pyrrole vapor rather than liquid impregnation. However, the nitrogen speciation is independent of the impregnating process, with a similar contribution of pyrrolic (not discarding pyridonic), pyridinic and quaternary nitrogen as the most abundant species.

PtRu catalysts with low noble metal loading (20 wt. \%) and supported on nitrogen-doped ordered mesoporous carbons were synthesized by formate reduction method, and their activity was assessed 
in both acid and alkaline solutions for the electro-oxidation of methanol. $\mathrm{N}$ groups appear to favor the electroactivity of PtRu nanoparticles. On one hand, there is an enrichment of Pt on the surface of PtRu nanoparticles with the increase of surface nitrogen. This characteristic may cause an improvement of the methanol dehydrogenation kinetics. On the other hand, the intrinsic activity is also higher for the catalysts supported on the N-doped mesoporous carbons, confirming the positive effect of nitrogen-doping. Interestingly, the best catalyst in acid electrolyte presents lower activity than the best catalyst in alkaline electrolyte, both overcoming the activity of the PtRu catalyst supported on the bare CMK (un-doped).

Supplementary Materials: The following are available online at http:/ / www.mdpi.com/1996-1073/11/4/831/s1, Figure S1: TEM images of PtRu/CMK, PtRu/CMK-N-imp and PtRu/CMK-N-vap.

Acknowledgments: The work has received financial support from the Spanish Ministry of Economy and Competitiveness (MINECO) through projects ENE2014-52158-C2-1-R and 2-R (co-founded by FEDER) and from Aragon Government to the Fuel Conversion Group. M.J. Nieto-Monge has also received funding for her Ph.D. grant from MINECO. D. Sebastián acknowledges also MINECO for his Ramón y Cajal research contract (RYC-2016-20944).

Author Contributions: María Jesús Lázaro and Elena Pastor conceived and designed the experiments; María Jesús Nieto-Monge synthesized the materials and performed the experiments; David Sebastián, Sara Pérez-Rodríguez and Elena Pastor analyzed and discussed the data; María Jesús Nieto-Monge and Sara Pérez-Rodríguez contributed reagents/materials/analysis tools; David Sebastián and Sara Pérez-Rodríguez wrote the paper; all authors revised the manuscript.

Conflicts of Interest: The authors declare no conflict of interest.

\section{References}

1. Antolini, E.; Gonzalez, E.R. Alkaline direct alcohol fuel cells. J. Power Sources 2010, 195, 3431-3450. [CrossRef]

2. Aricò, A.S.; Baglio, V.; Antonucci, V. Direct Methanol Fuel Cells; Nova Science Publishers, Inc.: New York, NY, USA, 2010; ISBN 9781608768653.

3. Sgroi, M.F.; Zedde, F.; Barbera, O.; Stassi, A.; Sebastián, D.; Lufrano, F.; Baglio, V.; Aricò, A.; Bonde, J.L.; Schuster, M. Cost Analysis of Direct Methanol Fuel Cell Stacks for Mass Production. Energies 2016, 9, 1008. [CrossRef]

4. Sebastián, D.; Serov, A.; Matanovic, I.; Artyushkova, K.; Atanassov, P.; Aricò, A.S.; Baglio, V. Insights on the extraordinary tolerance to alcohols of Fe-N-C cathode catalysts in highly performing direct alcohol fuel cells. Nano Energy 2017, 34, 195-204. [CrossRef]

5. Zhao, X.; Yin, M.; Ma, L.; Liang, L.; Liu, C.; Liao, J.; Lu, T.; Xing, W. Recent advances in catalysts for direct methanol fuel cells. Energy Environ. Sci. 2011, 4, 2736-2753. [CrossRef]

6. Lo Vecchio, C.; Aricò, A.S.; Monforte, G.; Baglio, V. EDTA-derived CoNC and FeNC electro-catalysts for the oxygen reduction reaction in acid environment. Renew. Energy 2018, 120, 342-349. [CrossRef]

7. Hsin, Y.L.; Hwang, K.C.; Yeh, C.-T. Poly(vinylpyrrolidone)-Modified Graphite Carbon Nanofibers as Promising Supports for PtRu Catalysts in Direct Methanol Fuel Cells. J. Am. Chem. Soc. 2007, 129, 9999-10010. [CrossRef] [PubMed]

8. Iwasita, T.; Hoster, H.; John-Anacker, A.; Lin, W.F.; Vielstich, W. Methanol Oxidation on PtRu Electrodes. Influence of Surface Structure and Pt-Ru Atom Distribution. Langmuir 2000, 16, 522-529. [CrossRef]

9. Sebastian, D.; Stassi, A.; Siracusano, S.; Vecchio, C.L.; Arico, A.S.; Baglio, V. Influence of Metal Oxide Additives on the Activity and Stability of PtRu/C for Methanol Electro-Oxidation. J. Electrochem. Soc. 2015, 162, F713-F717. [CrossRef]

10. Huang, L.; Zhang, X.; Wang, Q.; Han, Y.; Fang, Y.; Dong, S. Shape-Control of Pt-Ru Nanocrystals: Tuning Surface Structure for Enhanced Electrocatalytic Methanol Oxidation. J. Am. Chem. Soc. 2018, 140, 1142-1147. [CrossRef] [PubMed]

11. Sebastián, D.; Suelves, I.; Pastor, E.; Moliner, R.; Lázaro, M.J. The effect of carbon nanofiber properties as support for PtRu nanoparticles on the electrooxidation of alcohols. Appl. Catal. B Environ. 2013, 132, $13-21$. [CrossRef] 
12. Wang, Q.; Zhao, Z.; Jia, Y.; Wang, M.; Qi, W.; Pang, Y.; Yi, J.; Zhang, Y.; Li, Z.; Zhang, Z. Unique Cu@CuPt Core-Shell Concave Octahedron with Enhanced Methanol Oxidation Activity. ACS Appl. Mater. Interfaces 2017, 9, 36817-36827. [CrossRef] [PubMed]

13. Huang, H.; Hu, X.; Zhang, J.; Su, N.; Cheng, J. Facile Fabrication of Platinum-Cobalt Alloy Nanoparticles with Enhanced Electrocatalytic Activity for a Methanol Oxidation Reaction. Sci. Rep. 2017, 7, 45555. [CrossRef] [PubMed]

14. Sharma, S.; Pollet, B.G. Support materials for PEMFC and DMFC electrocatalysts-A review. J. Power Sources 2012, 208, 96-119. [CrossRef]

15. Chetty, R.; Kundu, S.; Xia, W.; Bron, M.; Schuhmann, W.; Chirila, V.; Brandl, W.; Reinecke, T.; Muhler, M. PtRu nanoparticles supported on nitrogen-doped multiwalled carbon nanotubes as catalyst for methanol electrooxidation. Electrochim. Acta 2009, 54, 4208-4215. [CrossRef]

16. Cheng, Y.; Xu, C.; Shen, P.K.; Jiang, S.P. Effect of nitrogen-containing functionalization on the electrocatalytic activity of PtRu nanoparticles supported on carbon nanotubes for direct methanol fuel cells. Appl. Catal. B Environ. 2014, 158-159, 140-149. [CrossRef]

17. Sebastián, D.; Lázaro, M.J.; Moliner, R.; Suelves, I.; Aricò, A.S.; Baglio, V. Oxidized carbon nanofibers supporting PtRu nanoparticles for direct methanol fuel cells. Int. J. Hydrog. Energy 2014, 39, 5414-5423. [CrossRef]

18. Gálvez, M.E.; Calvillo, L.; Alegre, C.; Sebastián, D.; Suelves, I.; Pérez-Rodríguez, S.; Celorrio, V.; Pastor, E.; Pardo, J.I.; Moliner, R.; et al. Nanostructured carbon materials as supports in the preparation of direct methanol fuel cell electrocatalysts. Catalysts 2013, 3, 671-682. [CrossRef]

19. Zhao, S.; Yin, H.; Du, L.; Yin, G.; Tang, Z.; Liu, S. Three dimensional N-doped graphene/PtRu nanoparticle hybrids as high performance anode for direct methanol fuel cells. J. Mater. Chem. A 2014, 2, 3719-3724. [CrossRef]

20. Alegre, C.; Baquedano, E.; Galvez, M.E.; Moliner, R.; Lazaro, M.J. Tailoring carbon xerogels' properties to enhance catalytic activity of Pt catalysts towards methanol oxidation. Int. J. Hydrog. Energy 2015, 40, 14736-14745. [CrossRef]

21. Alegre, C.; Gálvez, M.; Moliner, R.; Lázaro, M. Influence of the Synthesis Method for Pt Catalysts Supported on Highly Mesoporous Carbon Xerogel and Vulcan Carbon Black on the Electro-Oxidation of Methanol. Catalysts 2015, 5, 392-405. [CrossRef]

22. Maiyalagan, T.; Alaje, T.O.; Scott, K. Highly Stable Pt-Ru Nanoparticles Supported on Three-Dimensional Cubic Ordered Mesoporous Carbon (Pt-Ru/CMK-8) as Promising Electrocatalysts for Methanol Oxidation. J. Phys. Chem. C 2012, 116, 2630-2638. [CrossRef]

23. Dong, C.-D.; Chen, C.-W.; Chen, C.-F.; Hung, C.-M. Platinum particles supported on mesoporous carbons: Fabrication and electrocatalytic performance in methanol-tolerant oxygen-reduction reactions. Sci. Rep. 2015, 4, 5790. [CrossRef] [PubMed]

24. Walcarius, A. Mesoporous materials and electrochemistry. Chem. Soc. Rev. 2013, 42, 4098-4140. [CrossRef] [PubMed]

25. Joo, S.H.; Pak, C.; You, D.J.; Lee, S.-A.; Lee, H.I.; Kim, J.M.; Chang, H.; Seung, D. Ordered mesoporous carbons (OMC) as supports of electrocatalysts for direct methanol fuel cells (DMFC): Effect of carbon precursors of OMC on DMFC performances. Electrochim. Acta 2006, 52, 1618-1626. [CrossRef]

26. Bruno, M.M.; Petruccelli, M.A.; Viva, F.A.; Corti, H.R. Mesoporous carbon supported PtRu as anode catalyst for direct methanol fuel cell: Polarization measurements and electrochemical impedance analysis of mass transport. Int. J. Hydrog. Energy 2013, 38, 4116-4123. [CrossRef]

27. Calderón, J.; Calvillo, L.; Lázaro, M.; Rodríguez, J.; Pastor, E. Effect of the Dendrimer Generation Used in the Synthesis of Pt-Ru Nanoparticles Supported on Carbon Nanofibers on the Catalytic Activity towards Methanol Oxidation. Energies 2017, 10, 159. [CrossRef]

28. Alegre, C.; Sebastián, D.; Gálvez, M.E.; Baquedano, E.; Moliner, R.; Aricò, A.S.; Baglio, V.; Lázaro, M.J. N-Doped Carbon Xerogels as Pt Support for the Electro-Reduction of Oxygen. Materials 2017, 10, 1092. [CrossRef] [PubMed]

29. Zhou, Y.; Neyerlin, K.; Olson, T.S.; Pylypenko, S.; Bult, J.; Dinh, H.N.; Gennett, T.; Shao, Z.; O’Hayre, R. Enhancement of Pt and Pt-alloy fuel cell catalyst activity and durability via nitrogen-modified carbon supports. Energy Environ. Sci. 2010, 3, 1437-1446. [CrossRef] 
30. Su, F.; Tian, Z.; Poh, C.K.; Wang, Z.; Lim, S.H.; Liu, Z.; Lin, J. Pt Nanoparticles Supported on Nitrogen-Doped Porous Carbon Nanospheres as an Electrocatalyst for Fuel Cells. Chem. Mater. 2010, 22, 832-839. [CrossRef]

31. Lei, M.; Wang, J.; Li, J.R.; Wang, Y.G.; Tang, H.L.; Wang, W.J. Emerging methanol-tolerant AlN nanowire oxygen reduction electrocatalyst for alkaline direct methanol fuel cell. Sci. Rep. 2014, 4, 6013. [CrossRef] [PubMed]

32. Liu, Z.; Nie, H.; Yang, Z.; Zhang, J.; Jin, Z.; Lu, Y.; Xiao, Z.; Huang, S. Sulfur-nitrogen co-doped three-dimensional carbon foams with hierarchical pore structures as efficient metal-free electrocatalysts for oxygen reduction reactions. Nanoscale 2013, 5, 3283-3288. [CrossRef] [PubMed]

33. Wang, S.; Cochell, T.; Manthiram, A. Boron-doped carbon nanotube-supported Pt nanoparticles with improved CO tolerance for methanol electro-oxidation. Phys. Chem. Chem. Phys. 2012, 14, 13910-13913. [CrossRef] [PubMed]

34. Liu, Z.; Shi, Q.; Peng, F.; Wang, H.; Yu, H.; Li, J.; Wei, X. Enhanced methanol oxidation activity of Pt catalyst supported on the phosphorus-doped multiwalled carbon nanotubes in alkaline medium. Catal. Commun. 2012, 22, 34-38. [CrossRef]

35. Alegre, C.; Sebastián, D.; Gálvez, M.E.; Moliner, R.; Lázaro, M.J. Sulfurized carbon xerogels as Pt support with enhanced activity for fuel cell applications. Appl. Catal. B Environ. 2016, 192, 260-267. [CrossRef]

36. Liu, Z.; Su, F.; Zhang, X.; Tay, S.W. Preparation and characterization of PtRu nanoparticles supported on nitrogen-doped porous carbon for electrooxidation of methanol. ACS Appl. Mater. Interfaces 2011, 3, 3824-3830. [CrossRef] [PubMed]

37. Lv, R.; Cui, T.; Jun, M.-S.; Zhang, Q.; Cao, A.; Su, D.S.; Zhang, Z.; Yoon, S.-H.; Miyawaki, J.; Mochida, I.; et al. Open-Ended, N-Doped Carbon Nanotube-Graphene Hybrid Nanostructures as High-Performance Catalyst Support. Adv. Funct. Mater. 2011, 21, 999-1006. [CrossRef]

38. Luque-Centeno, J.M.; Martínez-Huerta, M.V.; Sebastián, D.; Lemes, G.; Pastor, E.; Lázaro, M.J. Bifunctional N-doped graphene $\mathrm{Ti}$ and $\mathrm{Co}$. nanocomposites for the oxygen reduction and evolution reactions. Renew. Energy 2018, 125, 182-192. [CrossRef]

39. Pels, J.R.; Kapteijn, F.; Moulijn, J.A.; Zhu, Q.; Thomas, K.M. Evolution of nitrogen functionalities in carbonaceous materials during pyrolysis. Carbon 1995, 33, 1641-1653. [CrossRef]

40. Garcia, G.; Baglio, V.; Stassi, A.; Pastor, E.; Antonucci, V.; Aricò, A.S. Investigation of Pt-Ru nanoparticle catalysts for low temperature methanol electro-oxidation. J. Solid State Electrochem. 2007, 11, 1229-1238. [CrossRef]

41. Gan, L.; Du, H.; Li, B.; Kang, F. Influence of reaction temperature on the particle-composition distributions and activities of polyol-synthesized Pt-Ru/C catalysts for methanol oxidation. J. Power Sources 2009, 191, 233-239. [CrossRef]

42. Guo, J.; Sun, G.; Shiguo, S.; Shiyou, Y.; Weiqian, Y.; Jing, Q.; Yushan, Y.; Qin, X. Polyol-synthesized PtRu/C and PtRu black for direct methanol fuel cells. J. Power Sources 2007, 168, 299-306. [CrossRef]

43. Celorrio, V.; Calvillo, L.; Pérez-Rodríguez, S.; Lázaro, M.J.; Moliner, R. Modification of the properties of carbon nanocoils by different treatments in liquid phase. Microporous Mesoporous Mater. 2011, 142, 55-61. [CrossRef]

44. Kim, J.; Jang, J.-S.; Peck, D.-H.; Lee, B.; Yoon, S.-H.; Jung, D.-H. Methanol-Tolerant Platinum-Palladium Catalyst Supported on Nitrogen-Doped Carbon Nanofiber for High Concentration Direct Methanol Fuel Cells. Nanomaterials 2016, 6, 148. [CrossRef] [PubMed]

45. Wood, K.N.; O'Hayre, R.; Pylypenko, S. Recent progress on nitrogen/carbon structures designed for use in energy and sustainability applications. Energy Environ. Sci. 2014, 7, 1212-1249. [CrossRef]

46. Calderón, J.C.; García, G.; Calvillo, L.; Rodríguez, J.L.; Lázaro, M.J.; Pastor, E. Electrochemical oxidation of $\mathrm{CO}$ and methanol on $\mathrm{Pt}-\mathrm{Ru}$ catalysts supported on carbon nanofibers: The influence of synthesis method. Appl. Catal. B Environ. 2015, 165, 676-686. [CrossRef]

47. Dos Santos, L.; Colmati, F.; Gonzalez, E.R. Preparation and characterization of supported Pt-Ru catalysts with a high Ru content. J. Power Sources 2006, 159, 869-877. [CrossRef]

48. Nieto-Márquez, A.; Toledano, D.; Sánchez, P.; Romero, A.; Valverde, J.L. Impact of nitrogen doping of carbon nanospheres on the nickel-catalyzed hydrogenation of butyronitrile. J. Catal. 2010, 269, 242-251. [CrossRef]

49. Roy, S.C.; Harding, A.W.; Russell, A.E.; Thomas, K.M. Spectroelectrochemical Study of the Role Played by Carbon Functionality in Fuel Cell Electrodes. J. Electrochem. Soc. 1997, 144, 2323-2328. [CrossRef] 
50. Tripkovic, A.V.; Popovic, K.D.; Grgur, B.N.; Blizanac, B.; Ross, P.N.; Markovic, N.M. Methanol electrooxidation on supported Pt and PtRu catalysts in acid and alkaline solutions. Electrochim. Acta 2002, 47, 3707-3714. [CrossRef]

51. Zhang, L.; Gao, A.; Liu, Y.; Wang, Y.; Ma, J. PtRu nanoparticles dispersed on nitrogen-doped carbon nanohorns as an efficient electrocatalyst for methanol oxidation reaction. Electrochim. Acta 2014, 132, 416-422. [CrossRef]

52. Pérez-Rodríguez, S.; Rillo, N.; Lázaro, M.J.; Pastor, E. Pd catalysts supported onto nanostructured carbon materials for $\mathrm{CO}_{2}$ valorization by electrochemical reduction. Appl. Catal. B Environ. 2015, 163, 83-95. [CrossRef]

53. Lázaro, M.J.; Calvillo, L.; Bordejé, E.G.; Moliner, R.; Juan, R.; Ruiz, C.R. Functionalization of ordered mesoporous carbons synthesized with SBA-15 silica as template. Microporous Mesoporous Mater. 2007, 103, 158-165. [CrossRef]

54. Valle-Vigón, P.; Sevilla, M.; Fuertes, A.B. Functionalization of mesostructured silica-carbon composites. Mater. Chem. Phys. 2013, 139, 281-289. [CrossRef]

55. Naumkin, A.V.; Kraut-Vass, A.; Gaarenstroom, S.W.; Powell, C.J. NIST X-ray Photoelectron Spectroscopy Database, NIST Standard Reference Database 20, Version 4.1. 2017. Available online: http:/ / srdata.nist.gov/ xps/Default.aspx (accessed on 20 December 2017).

56. Briggs, D. Handbook of X-Ray Photoelectron Spectroscopy; Wanger, C.D., Riggs, W.M., Davis, L.E., Moulder, J.F., Muilenberg, G.E., Eds.; Perkin-Elmer Corp.: Eden Prairie, MN, USA, 1979.

(C) 2018 by the authors. Licensee MDPI, Basel, Switzerland. This article is an open access article distributed under the terms and conditions of the Creative Commons Attribution (CC BY) license (http://creativecommons.org/licenses/by/4.0/). 